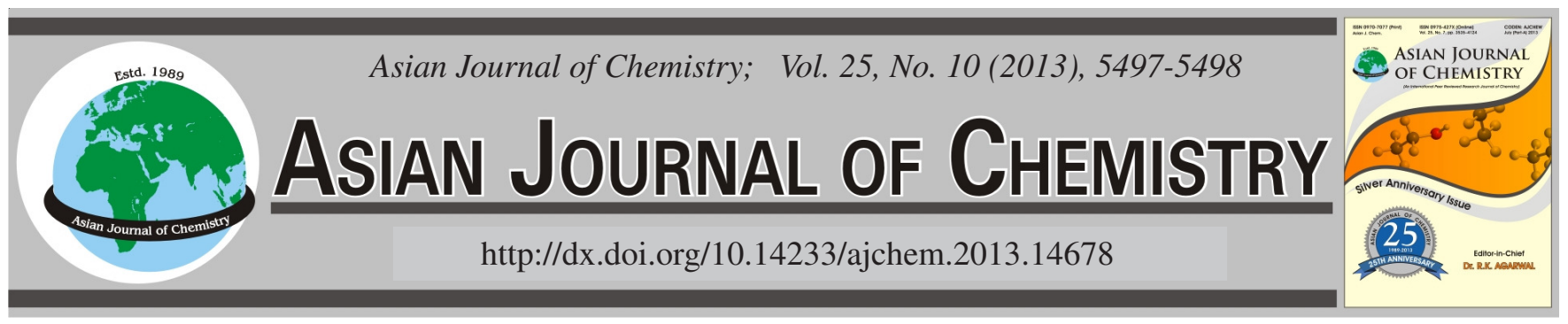

NOTE

\title{
Hydrothermal Synthesis and Crystal Structure of Cd(II) Coordination Polymer
}

BIN LI

Institute of Chemical Engineering and Environment, Wei Fang University of Science and Technology, Shandong 262700, P.R. China

Corresponding author: E-mail: whyull@yeah.net

(Received: 15 October 2012;

Accepted: 15 April 2013)

AJC-13241

One new cadmium compound $\{[\mathrm{Cd}(\mathrm{L})] \text {-(bip) }\}_{\mathrm{n}}(1)\left[\mathrm{H}_{2} \mathrm{~L}=5\right.$-hydroxyisophthalic acid and bip = 1,5-bis(2-methyl-imidazol-1-yl) pentane $]$ has been successfully synthesized. Compound shows a two-dimensional frameworks. The bip ligands are filled the hole of 2D layer.

Key Words: Coordination polymer, Crystal structure, Cadmium(II).

The rational design and construction of novel functional metal-organic frameworks is currently of great interest for the past decade due to their diverse topologies and potential applications in gas storage, magnetism, catalysis and luminescence ${ }^{1-4}$. Although the rapid progress in metal-organic frameworks has been made, it is also a great challenge to rationally prepare and control the structures and composition of target products in crystal engineering because of the difficult prediction of either the composition or the structure of the reaction product.

All reagent and solvents employed were commercially available and used as received without further purification.

Preparation of compound: A mixture of 5-hydroxyisophthalic acid (1 mmol), $\mathrm{Cd}(\mathrm{OAc})_{2} \cdot 2 \mathrm{H}_{2} \mathrm{O}(1 \mathrm{mmol}), 1,5-$ bis $(2-$ methyl-imidazol-1-yl) pentane $(1 \mathrm{mmol})$ and distilled water $(15 \mathrm{~mL})$ was heated in a $25 \mathrm{~mL}$ stainless steel reactor with a Teflon liner $160^{\circ} \mathrm{C}$ for $96 \mathrm{~h}$, followed by slow cooling to room temperature. Yellow crystals of the compound formed.

X-crystallography: Suitable single crystals were selected under a polarizing microscope and fixed with epoxy cement on fine glass fibers which were mounted on a Bruker Smart
$1000 \mathrm{CCD}$ diffractometer with a $\mathrm{MoK}_{\alpha}$ radiation $(\lambda=0.71073$ $\AA$ ) at 293(2) K. The hydrogen atoms bound to carbon were located by geometrically calculations. All non-hydrogen atoms were refined by full-matrix least-squares techniques. All calculations were performed by the SHELXTL 97 program $^{5}$. The crystallographic data and experimental details of structural analyses for coordination polymers are summarized in Table1. Selected bond and angle parameters are listed in Table-2. CCDC: 862871 . The molecular structure of Cd(II) coordination polymer at $30 \%$ probability displacement ellipsoids is given in Fig. 1.

Structure description: Single-crystal X-ray analyses revealed that the compounds $\mathbf{1}$ crystallizes in orthorhombic the Pccn group. The Cd1 atom is six-coordination with a distorted octahedral coordination geometry define by six oxygen atom. The Cd-O lengths are ranging from 2.2416(14) to 2.5038(14) $\AA$. In compound, the carboxylate groups adopt two coordinated modes: bis-chelating and monodentate modes, which lead to form a two-dimensional layer structure and 1,5-bis(2-methylimidazol-1-yl) pentane ligands are filled in the hole (Fig. 2).

TABLE-1

CRYSTALLOGRAPHIC DATA AND STRUCTURE REFINEMENT SUMMARY FOR COMPLEX

\begin{tabular}{llll}
\hline Empirical formula & $\mathrm{C}_{38} \mathrm{H}_{30} \mathrm{~N}_{4} \mathrm{O}_{8} \mathrm{Cd}_{2}$ & $\mathrm{Z}$, Calculated density $\left(\mathrm{mg} / \mathrm{m}^{3}\right)$ & $1,1.629$ \\
Formula weight & 2827.88 & Absorption coefficient $\left(\mathrm{mm}^{-1}\right)$ & 0.824 \\
Crystal system space group & Monoclinic, $\mathrm{Cc}$ & $\mathrm{F}(000)$ & 1440 \\
Unit cell dimensions & $\mathrm{a}=14.3898(6) \AA$ & Limiting indices & $-17 \leq \mathrm{h} \leq 18$ \\
& $\mathrm{~b}=14.5914(6) \AA$ & & $-18 \leq \mathrm{k} \leq 17$ \\
& $\mathrm{c}=13.8173(6) \AA$ & & $-17 \leq 1 \leq 11$ \\
Volume $\left(\AA^{3}\right)$ & $2881.8(2)$ & Largest diff. peak and hole $\left(\mathrm{e} / \AA^{3}\right)$ & 0.595 and- 0.626 \\
$\theta$ Range for data collection & $1.99-27.50$ & Goodness-of-fit on $\mathrm{F}^{2}$ & 1.057 \\
Final $\mathrm{R}$ indices $[\mathrm{I}>2 \sigma(\mathrm{I})]$ & $\mathrm{R}_{1}=0.0253 \mathrm{wR}_{2}=0.0669$ & $\mathrm{R}$ indices (all data) & $\mathrm{R}_{1}=0.0269, \mathrm{wR}_{2}=0.0680$ \\
\hline
\end{tabular}


TABLE-2

SELECTED BOND LENGTHS $(\AA ̊)$ AND ANGLES $\left(^{\circ}\right)$ FOR COMPLEX

\begin{tabular}{|c|c|c|c|}
\hline $\mathrm{Cd} 1-\mathrm{O} 4^{\mathrm{i}}$ & $2.2416(14)$ & $\mathrm{Cdl}^{-O} 1^{\mathrm{iii}}$ & $2.3117(14)$ \\
\hline $\mathrm{Cd} 1-\mathrm{O} 4^{\mathrm{ii}}$ & $2.2416(14)$ & $\mathrm{Cdl}-\mathrm{O} 2^{\mathrm{iii}}$ & $2.5038(14)$ \\
\hline Cd1-O1a & $2.3117(14)$ & $\mathrm{Cdl}-\mathrm{O} 2 \mathrm{a}$ & 2.5038 \\
\hline $\mathrm{O} 4-\mathrm{Cd} 1-\mathrm{O} 4^{\mathrm{ii}}$ & $102.69(8)$ & $\mathrm{O} 4^{\mathrm{ii}}-\mathrm{Cd} 1-\mathrm{O} 1^{\mathrm{iii}}$ & $127.85(5)$ \\
\hline $\mathrm{O} 4-\mathrm{Cd} 1-\mathrm{O} 1 \mathrm{a}$ & $127.85(5)$ & Ola-Cd1-O1 $1^{\mathrm{iii}}$ & $125.85(7)$ \\
\hline $\mathrm{O} 4^{\mathrm{ii}}-\mathrm{Cd} 1-\mathrm{O} 1 \mathrm{a}$ & $87.42(5)$ & $\mathrm{O} 4^{\mathrm{i}}-\mathrm{Cd} 1-\mathrm{O} 2^{\mathrm{iii}}$ & $139.16(5)$ \\
\hline $\mathrm{O} 4^{\mathrm{i}}-\mathrm{Cd} 1-\mathrm{O} 1^{\text {iii }}$ & $87.42(5)$ & $\mathrm{O} 4^{\mathrm{ii}}-\mathrm{Cd} 1-\mathrm{O} 2^{\mathrm{iii}}$ & $92.44(5)$ \\
\hline
\end{tabular}

Symmetry codes: (i) $-x+1 / 2, y+1 / 2,-z+1 / 2$; (ii) $x-1 / 2, y+1 / 2, z$; (iii) $-x$, $\mathrm{y},-\mathrm{z}+1 / 2$

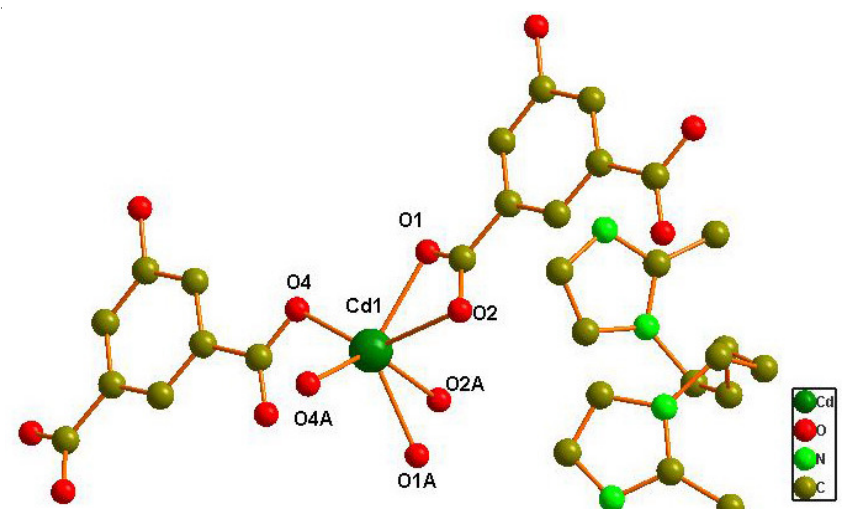

Fig. 1. Molecular structure of the title compound at $30 \%$ probability displacement ellipsoids

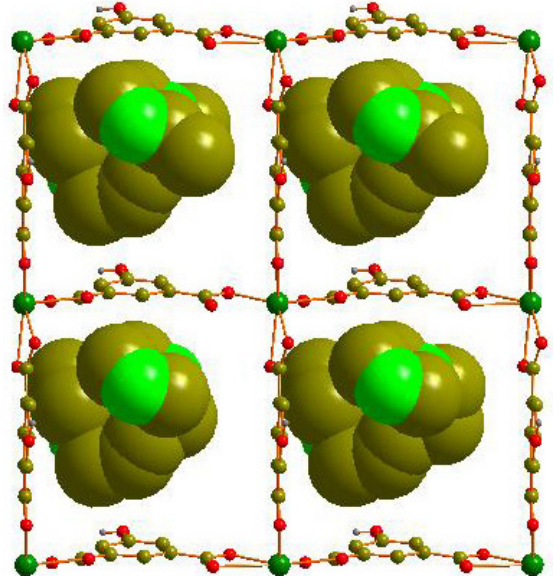

Fig. 2. 2D layer structure of compound and the bip ligands filled in the hole

\section{REFERENCES}

1. J.Y. Lee, O.K. Farha, J. Roberts, K.A. Scheidt, S.T. Nguyen and J.T. Hupp, Chem. Soc. Rev., 38, 1450 (2009).

2. S.S. Kaye, A. Dailly, O.M. Yaghi and J.R. Long, J. Am. Chem. Soc., 129, 14176 (2007).

3. C. Kachi-Terajima, K. Yanagi, T. Kaziki, T. Kitazawa and M. Hasegawa, Dalton Trans., 40, 2249 (2011).

4. R. Banerjee, H. Furukawa, D. Britt, C. Knobler, M. O'Keeffe and O.M. Yaghi, J. Am. Chem. Soc., 131, 3875 (2009).

5. G.M. Sheldrick, SHELXTL97, Program for the Refinement of Crystal Structure, University of Gottingen, Germany (1997). 